\title{
KORELASI KELUHAN KESEHATAN IBU DAN ANGKATAN KERJA PEREMPUAN TERHADAP PEROKOK ANAK
}

\author{
Shaela Mayasari \\ BPS Kabupaten Maros \\ e-mail: shaela@bps.go.id
}

\begin{abstract}
ABSTRAK
Persentase jumlah perokok anak ( $\leq 18$ tahun) terus mengalami kenaikan tiap tahunnya. Merokok di usia sangat muda tentu berpengaruh pada kesehatan anak. Tidak hanya sekarang, tapi di masa depan. Untuk itu, diharapkan peran orang tua bisa membuat anak menjauhi aktifitas merokok. Maka penting untuk mengetahui kualitas kesehatan ibu dan ketersediaan waktu luangnya dalam mendidik anak. Penelitian ini bertujuan untuk menggambarkan pengaruh keluhan kesehatan yang dialami ibu dan pengaruh ibu bekerja yang masuk sebagai angkatan kerja perempuan terhadap perokok anak. Jenis penelitian ini kuantitatif. Dengan metode analisis uji korelasi sederhana dan statistik deskriptif. Adapun sumber datanya ialah data sekunder BPS tahun 2016-2018. Hasil dari penelitian ini menyatakan hubungan antara keluhan kesehatan yang dialami ibu berkorelasi kuat dengan perokok anak, dimana nilai $\mathrm{R}^{2}=0.9663$. Hubungan antara perokok anak dengan jumlah angkatan kerja perempuan, juga menunjukkan korelasi positif yang kuat dimana nilai $\mathrm{R}^{2}$ nya 0.9289 . Karena keterbatasan data dan waktu, penelitian ini hanya bisa menggambarkan perkembangan pekerja anak, perkembangan keluhan kesehatan ibu, dan perkembangan angkatan kerja perempuan. Selanjutnya diperlukan penelitian lebih komperehensif lagi terhadap hubungan ketiganya.
\end{abstract}

Kata kunci: rokok, anak, ibu

\begin{abstract}
The percentage of child smokers ( $\leq 18$ years) continues to increase every year. Smoking at a very young age certainly affects the health of children. Not only now, but in the future. For this reason, it is hoped that the role of parents can make children stay away from smoking. So it is important to know the quality of maternal health and the availability of free time in educating children. This study aims to describe the effect of health complaints experienced by mothers and the influence of working mothers who enter the female workforce on child smokers. This type of research is quantitative. With the simple correlation test analysis method and descriptive statistics. The source of the data is BPS secondary data for 2016-2018. The results of this study stated the relationship between health complaints experienced by mothers strongly correlated with child smokers, where the value of $R 2=0.9663$. The relationship between child smokers and the number of female workforce, also shows a strong positive correlation where the R2 value is 0.9289 . Because of limited data and time, this study can only describe the development of child labor, the development of maternal health complaints, and the development of the female workforce. Furthermore, more comprehensive research is needed on the relationship of the three.
\end{abstract}

Keywords: smoke, child, mother 


\section{PENDAHULUAN}

Rokok adalah musuh besar bangsa saat ini, dengan beragam zat berbahaya di dalamnya. Semakin muda seseorang mulai merokok, makin besar risiko orang tersebut mendapat penyakit saat tua. Generasi muda memiliki tingkat penyebaran yang tinggi menjadi perokok pemula, bahkan di wilayah tertentu merokok dimulai di usia balita. Terdapat masyarakat yang juga dikenal kelompok rentan, yaitu kelompok dengan prevalensi tinggi sehingga memiliki kemungkinan yang besar melakukan tindakan merokok (Munir, 2018).

Berdasarkan data dari Riskesdas tahun 2013 dapat diketahui bahwa perilaku merokok pada penduduk yang berusia $>15$ tahun cenderung mengalami peningkatan yaitu sebesar $34,2 \%$ pada tahun 2007 menjadi sebesar 36,3\% pada tahun 2013. Prevalensi perokok laki-laki adalah sebesar $64,9 \%$ dan prevalensi perokok perempuan sebesar $2,1 \%$. Diantara prevalensi tersebut ditemukan sebesar $1,4 \%$ perokok remaja yang berusia 10-14 tahun.

Fakta lain juga diungkap Martini \& Sulistyowati (2005) dalam penelitiannya, dikatakan bahwa remaja yang berusia 13- 21 tahun terdapat sebanyak $32 \%$ pernah merokok dan $20 \%$ sebagai perokok aktif. Usia yang paling banyak diketahui seseorang mulai merokok adalah pada usia 10 tahun dan 17 tahun, dan beberapa remaja mulai merokok setelah usia 17 tahun.

Dikatakan Komalasari dan Helmi, (2012) bahwa proses menjadi perokok dimulai sejak masa remaja. Untuk mencegahnya, dilakukan melalui transmisi dari generasi sebelumnya. Yaitu transmisi vertikal dari lingkungan keluarga dan lebih spesifik lagi dengan melihat sikap permisif tidaknya orangtua terhadap perilaku merokok remaja.

Menyadari ibu adalah madrasah pertama anak, maka kualitas kesehatan ibu merupakan gambaran kesehatan keluarga. Ibu yang sehat, baik fisik, jasmani, maupun rohani akan melahirkan dan membesarkan anak-anak dengan pola asuh maksimal. Anak sehat merupakan aset penting bagi bangsa. Hal ini dikarenakan anak merupakan penentu nasib bangsa di masa yang akan datang. (Nastia dkk, 2014)

Ibu yang sehat dan memiliki waktu banyak dengan anak, diharapkan melahirkan anak yang produktif dan cerdas. Sebaliknya, jika ibu sering dalam keadaan tidak sehat dan terlalu banyak beraktifitas di luar, maka anak akan mencari pergaulan di lingkungan luar rumah. Tanpa pantauan yang baik, kecenderungan untuk mengikuti perilaku lingkungan yang negatif, salah satunya adalah dengan merokok.

Dewasa ini banyak perempuan yang berperan ganda dimana selain melakukan perkerjaan-pekerjaan rumah tangga juga bekerja diluar rumah dengan berbagai tujuan. Banyak manfaat yang dirasakan ibu yang bekerja di luar rumah. Selain mampu mengaktualisasikan potensinya, juga bisa menopang ekonomi keluarga. Namun seringkali masih timbul dilema ataupun konflik bagi ibu pekerja, khususnya terhadap kedekatan dengan keluarga dan anak (Yunita, 2017).

Perempuan yang bekerja memang memberikan dampak yang positif, namun disisi lain sering terjadi ketidak harmonisan di dalam keluarga. Hal ini disebabkan karena sulitnya membagi waktu antara berperan sebagai seorang wanita yang bekerja dan menjadi seorang istri sekaligus ibu yang bertanggung 
jawab dalam mengasuh, mendidik dan memenuhi kebutuhan anak dasar anak (Fitriyani dkk, 2016)

Dengan demikian, tujuan dari penelitian ini ingin menggambarkan peranan ibu terhadap perokok anak, jika ditinjau dari aspek keluhan kesehatan yang dialami ibu, dan aspek ketersediaan waktu ibu melalui pendekatan data angkatan kerja perempuan.

\section{METODE PENELITIAN}

Metode penelitian ini secara kuantitatif. Lokasi penelitian berlangsung di Jakarta. Pada Bulan Oktober - November 2019. Cakupan wilayahnya di seluruh wilayah Indonesia, mencakup 75.000 rumah tangga sampel Survei Sosial Ekonomi Nasional (Susenas) yang tersebar di 34 provinsi dan 514 kabupaten/kota di seluruh wilayah Indonesia. Pengolahan datanya menggunakan data sekunder BPS.

Analisa datanya menggunakan metode analisis statistik uji korelasi sederhana dan statistik deskriptif. Data yang digunakan menggunakan data sekunder yang berasal dari Publikasi Kesehatan Ibu Anak dan Data Ketenagakerjaan Indonesia BPS. Jenis data yang digunakan adalah data mengenai persentase perokok anak, persentase ibu yang mengalami keluhan kesehatan, dan data angkatan kerja perempuan. Data yang dipakai menggunakan data series tahun 2016 sampai dengan tahun 2018.

\section{HASIL DAN PEMBAHASAN}

Hasil penelitian berupa data karakteristik reponden dapat terlihat pada gambar berikut:

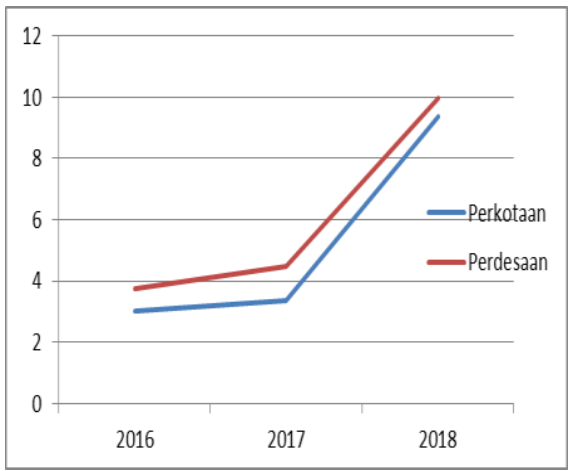

Gambar 1. Persentase Perokok Anak Berdasarkan Kelompok Umur

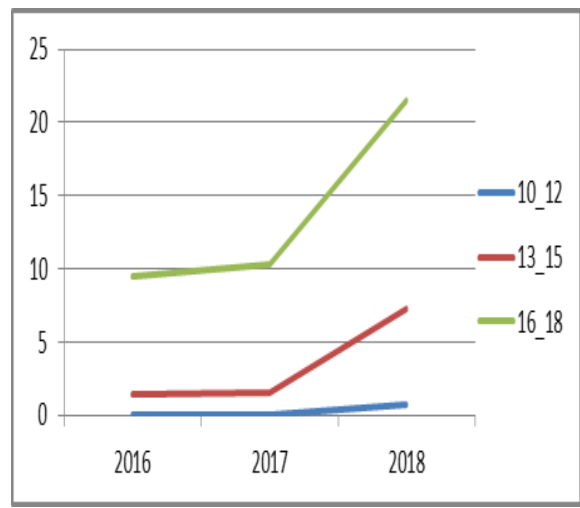

Gambar 2. Persentase Perokok Anak Berdasarkan Kelompok Umur

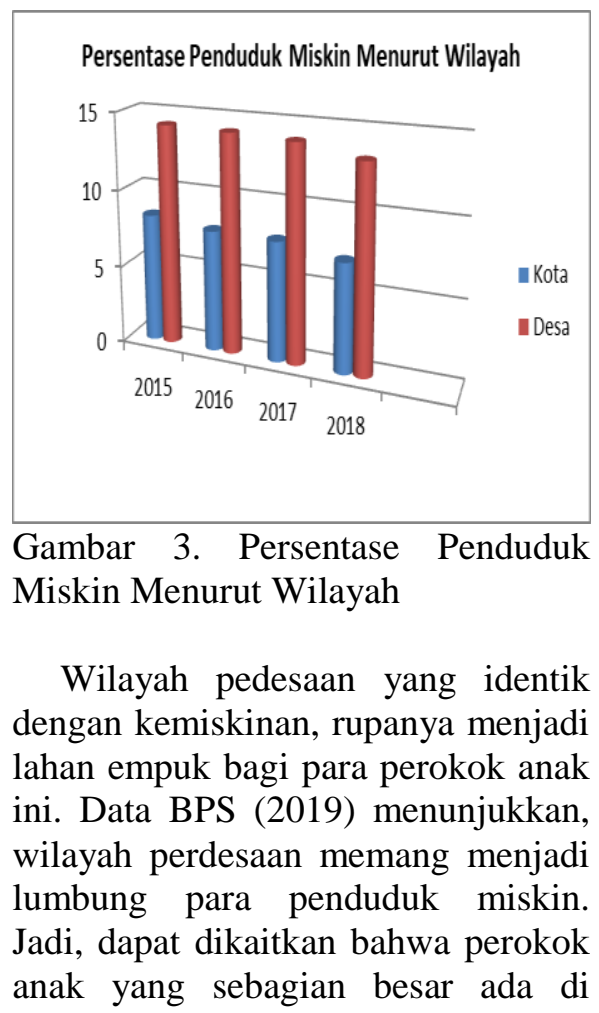


perdesaan, ialah juga mereka yang berasal dari keluarga miskin. Meski hal ini tentu membutuhkan kajian yang lebih mendalam lagi untuk melihat keterkaitan keduanya.

Grafik di atas menunjukkan persentase perokok anak terus mengalami peningkatan dari tahun ke tahun. Dan kenaikan yang paling mencolok terjadi pada tahun 2018. Dimana pada tahun itu, persentase perokok anak sebesar 9,65\%, naik dari tahun 2017 yang hanya $3.9 \%$. Dan berdasarkan kelompok umur, perokok anak terbesar berada dalam rentang usia 16-18 tahun.

Hal ini sejalan dengan penelitian yang telah dilakukan Munir (2018) bahwa rata-rata perokok anak berada di usia remaja menjelang 18 tahun. Masa remaja adalah merupakan masa kritis bagi para remaja untuk mencari identitas diri (identity crisis) yang

\section{Kesehatan Ibu}

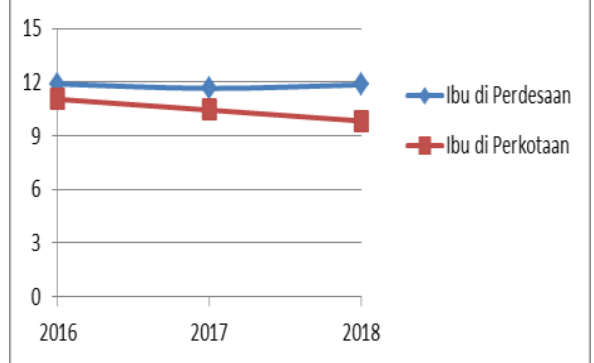

Gambar 4. Perkembangan Ibu Mengalami Gangguan Kesehatan

Dengan asumsi bahwa Ibu ialah madrasah pertama anak, maka tentu Ibu yang sehat dan tak mengalami keluhan kesehatan yang berpotensi mengganggu kegiatan sehari-harinya, diharap memberi tauladan dan pengajaran terbaik pada anak. Dalam kondisi sehat, ibu bisa mengontrol segala tindak tanduk anaknya, dan menegur anak jika melakukan hal-hal di luar kewajaran, misalnya merokok. mana para remaja akan berkembang untuk melakukan tugas utama dalam menemukan kejelasan identitas (sense of identity).

Hasil penelitian terbaru Hapsari (2018), menyatakan bahwa keputusan mahasiswa (termasuk anak menjelang 18 tahun) untuk merokok tidak hanya dipengaruhi oleh faktor sosial, namun lebih kepada faktor yang berasal dari dalam diri anak, seperti faktor psikologis, faktor pengetahuan produk, dan gaya hidup.

Dari keseluruhan identitas sosial yang terbentuk, perilaku merokok pada remaja khususnya, sudah menjadi budaya dalam struktur masyarakat. Dalam struktur masyarakat, perilaku merokok yang dilakukan remaja sudah bukan lagi hal yang dianggap aneh, melainkan suatu kewajaran (Nugroho, 2018).

Grafik di atas menunjukkan perkembangan ibu mengalami keluhan kesehatan yang terus bertambah tiap tahunnya. Hal ini penting diperhatikan. Karena jika Ibu sakit, dan kegiatan sehari-harinya terganggu, tentu akan mengurangi perhatian dan kasih sayang Ibu untuk anaknya. Sehingga anak bisa saja berbuat di luar kontrol.

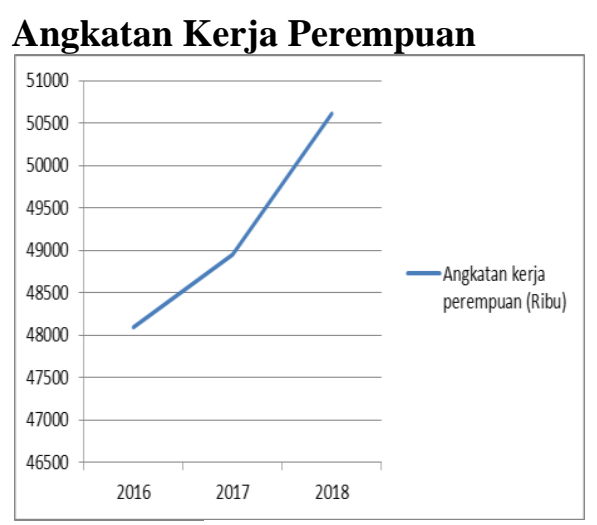

Gambar 5. Perkembangan Angkatan Kerja Perempuan (Ribu) 
Selain sehat, keberadaan ibu di rumah tentu diharap menciptakan lingkungan positif bagi anak. Karena dengan waktu dan kebersamaan yang intens, anak akan merasa mendapat perhatian dan kehangatan dari Ibunya. Sehingga segala pengaruh buruk yang datang dari luar, bisa diminimalisir.

Namun, data BPS (2019) dalam Survei Angkatan Kerja Nasional (Sakernas), menyebut angkatan kerja perempuan terus mengalami peningkatan signifikan tiap tahunnya. Yang mengindikasikan peran serta ibu dalam kelompok angkatan kerja, termasuk sedang bekerja dan sementara tidak bekerja terus meningkat.

Meski data ini tidak spesifik menjurus kepada kaum Ibu, namun perempuan dalam hal ini usia produktif (>15 tahun), mewakili keberadaan kaum ibu di tengahtengah masyarakat.

Hal ini sejalan dengan hasil penelitian Dewi (2012), semakin tinggi waktu yang digunakan perempuan dalam bekerja di luar rumah, maka makin tinggi kesempatan untuk mendapatkan tambahan pendapatan untuk keluarganya.

\section{Korelasi Keluhan Kesehatan Ibu dan Perokok Anak}

Dari hasil uji korelasi, diketahui bahwa kenaikan persentase keluhan kesehatan yang dialami ibu diikuti pula dengan naiknya persentase perokok anak tiap tahunnya.

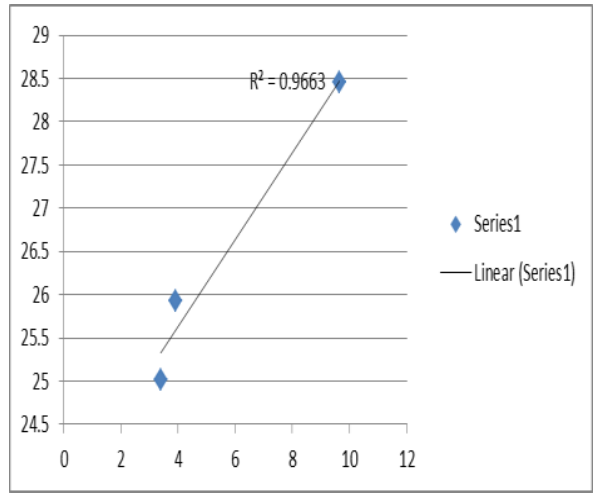

Gambar 6. Korelasi Keluhan Kesehatan Ibu dan Perokok Anak

Uji korelasi di atas menunjukkan korelasi positif. Dimana R2 $=0.9663$ menunjukkan hubungan yang kuat. Dimana nilai koefisien korelasi dengan range -1 sampai 1 . Semakin mendekati 1 artinya hubungan semakin kuat. Semakin mendekati -1 hubungannya juga semakin kuat, tetapi negatif. Jadi dari uji di atas menunjukkan ada korelasi positif antara persentase pekerja anak dan keluhan kesehatan yang dialami ibu. Meski tak bisa menjawab hubungan sebab akibat antar keduanya.

\section{Korelasi Angkatan Kerja Ibu dan Perokok Anak}

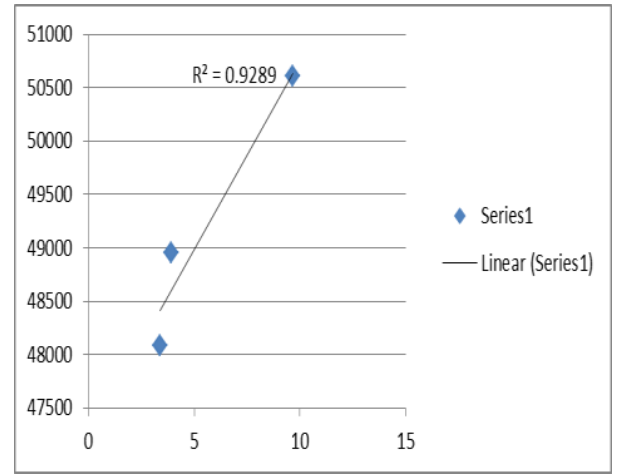

Gambar 7. Korelasi Angkatan Kerja Ibu dan Perokok Anak

Sejalan dengan uji korelasi sebelumnya, korelasi perokok anak dan angkatan kerja ibu juga menunjukkan hubungan positif R2 0.9289. Yang dapat diartikan 
kenaikan jumlah perokok anak tiap tahunnya, memiliki korelasi dengan kenaikan jumlah angkatan kerja perempuan. Meski angkatan kerja yang dimaksud, tak spesifik mewakili ibu. Namun meningkatnya angkatan kerja perempuan, bisa diduga menjadi salah satu sebab meningkatnya perokok anak.

Hal ini sejalan dengan uji korelasi sebelumnya, korelasi perokok anak dan angkatan kerja ibu juga menunjukkan hubungan positif R2 0.9289. Yang dapat diartikan kenaikan jumlah perokok anak tiap tahunnya, memiliki korelasi dengan kenaikan jumlah angkatan kerja perempuan. Meski angkatan kerja yang dimaksud, tak spesifik mewakili ibu. Namun meningkatnya angkatan kerja perempuan, bisa diduga menjadi salah satu sebab meningkatnya perokok anak.

Dikatakan Komalasari (2012), perilaku merokok lebih didasarkan atas pertimbangan emosional. Berkaitan dengan masalah tersebut upaya preventif maupun kuratif sebaiknya tidak menggunakan pendekatan kognitif seperti pemberian informasi bahaya-bahaya atau dampak negatif merokok, tetapi sentuhan-sentuhan afeksional perlu dilakukan. Yang sumber utamanya adalah dari sentuhan ibu.

Sejalan yang dituliskan Fitriani, dkk Perempuan yang bekerja memang memberikan dampak yang positif, namun disisi lain sering terjadi ketidak harmonisan di dalam keluarga. Hal ini disebabkan karena sulitnya membagi waktu antara berperan sebagai seorang wanita yang bekerja dan menjadi seorang istri sekaligus ibu yang bertanggung jawab dalam mengasuh, mendidik dan memenuhi kebutuhan anak

\section{KESIMPULAN}

a. Persentase perokok anak terus mengalami kenaikan tiga tahun terakhir. Berdasarkan status wilayah, perokok anak terbanyak berada di perdesaan. Sementara berdasarkan kelompok umur, terbanyak di usia 16-18 tahun.

b. Terdapat korelasi positif, antara kenaikan persentase keluhan kesehatan ibu dan kenaikan jumlah perokok anak.

c. Terdapat korelasi positif, antara kenaikan persentase angkatan kerja ibu dan kenaikan jumlah perokok anak.

\section{UCAPAN TERIMA KASIH}

Terimakasih Penulis haturkan kepada seluruh pihak yang telah membantu dalam penyusunan jurnal ini. Terkhusus untuk Pak Endan Suwandana dan Ibu Euis selaku motivator Penulis untuk terus berkarya menjadi fungsional yang produktif.

\section{REFERENSI}

Badan Pusat Statistik, 2019a. Profil kesehatan Ibu dan Anak 2018. Badan Pusat Statistik, Jakarta.

Badan Pusat Statistik, 2019b. Profil Ketenagakerjaan Indonesia 2018. Badan Pusat Statistik, Jakarta.

Dewi, P.M., 2012. Partisipasi Tenaga Kerja Perempuan dalam Meningkatkan Pendapatan Keluarga. JEKT 5, 119-124.

Fitriyani, Nurwati, N., Humaedi, S., 2016. Peran Ibu yang Bekerja Dalam Pemenuhan Kebutuhan Dasar Anak. Ris. PKM 3, 52-57.

Hapsari, A.Y., Muhammad, A.H., 2018. Keputusan Mahasiswa Universitas "X" Bandung untuk Merokok di Lingkungan Kampus yang Dipengaruhi oleh Faktor Sosial. Ultim. Manag. 10, 14-20.

Komasari, D., Helmi, A.F., 2000. Faktor-Faktor Penyebab Perilaku 
Merokok pada Remaja. J. Psikol. 1, 37-47.

Martini, S., Sulistyowati, M., 2005. The Determinants of Smoking Behavior among Teenagers in East Java Province, Indonesia. Econ. Tob. Control Pap.

Munir, M., 2018. Pengetahuan dan Sikap Remaja Tentang Risiko Merokok pada Santri Mahasiswa di Asrama UIN Sunan Ampel Surabaya. KLOROFIL 1, 93-104.

Nastia, G.I.P., Rachim, H.A., Irfan, M.,
2014. Promosi Kesehatan Ibu dan Anak Melalui Corporate Social Responsibility (CSR) Bidan Kesehatan Ibu dan Anak 111-121.

Nugroho, R.S., 2010. Perilaku Merokok Remaja (Perilaku Merokok Sebagai Identitas Sosial Remaja Dalam Pergaulan Di Surabaya). J. Ilm. Dep. Sosiol. FISIP Univ. Airlangga.

Yunita, R.D., 1999. Dilema Ibu Bekerja. Kognisi 3, 7-12. 